BBA 31057

\title{
Isolation and partial characterization of a basic protein from bovine sperm heads
}

In fish spermatozoa, protamines are associated with DNA. Little is known, however, about the basic protein that is associated with DNA in mammalian spermatozoa. This is largely due to the fact that no basic protein can be extracted from mammalian spermatozoa by the usual methods. Some authors have described the presence in mammalian spermatozoa of a basic protein that is rich in arginine and cysteine $^{1-3}$. They were unable, however, to characterize this protein to an appreciable extent. This communication describes the isolation and partial characterization of a basic protein from the heads of bull spermatozoa.

The heads of bull spermatozoa were separated from the tails by shearing a suspension of spermatozoa in water $(3 \mathrm{~g} / \mathrm{I} 0 \mathrm{ml})$ by means of a Bühler homogenizer for I 5 min at maximum speed. The suspension was then layered on an equal volume of $20 \%(\mathrm{w} / \mathrm{v})$ sucrose in water and centrifuged for $15 \mathrm{~min}$ at $1000 \times g$. The resulting sediment consisted of two layers: a white firmly packed bottom layer which consisted mainly of heads and a yellowish loosely packed upper layer which consisted of tails. By shaking the sediment with water the upper layer was removed. The bottom layer was resuspended in water and again centrifuged through a sucrose layer. After removal of a small loosely packed upper layer, the sediment now consisted almost exclusively of heads. The contamination with tails was less than $\mathrm{I} \%$.

The isolated heads were suspended ( $15 \mathrm{mg} / \mathrm{I} 0 \mathrm{ml}$ ) in a solution containing $5 \mathrm{M}$ guanidinium chloride, $0.28 \mathrm{M}$ 2-mercaptoethanol, $0.005 \mathrm{M}$ EDTA and $0.5 \mathrm{M}$ Tris- $\mathrm{HCl}$ ( $\mathrm{pH} 8.5$ ). Upon incubation for $60 \mathrm{~min}$ at $37^{\circ}$ the heads dissolved completely. Released sulfhydryl groups were then blocked by the addition of ethylenimine to a final concentration of $0.56 \mathrm{M}$ and further incubation for $90 \mathrm{~min}$ at $37^{\circ}$. The solution was then cooled and acidified by the addition of $1 / 5$ volume of a solution containing $5 \mathrm{M} \mathrm{HCl}$ and $2.5 \mathrm{M}$

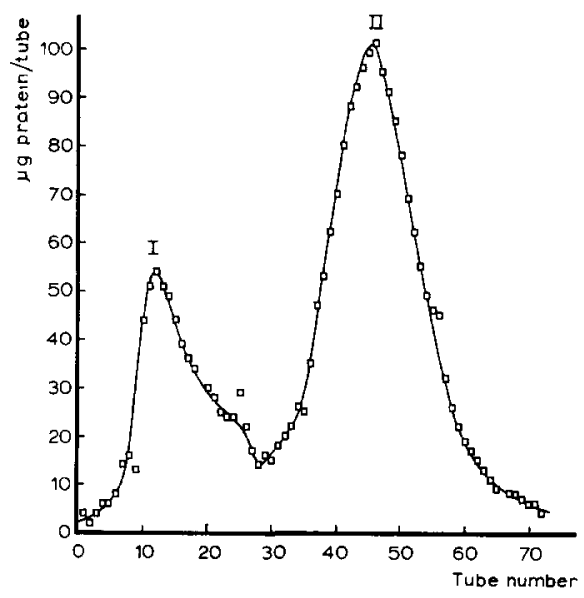

Fig. I. Chromatography of $2.6 \mathrm{mg}$ of the extracted head proteins on a Sephadex G-75 column $(1.8 \mathrm{~cm} \times 40 \mathrm{~cm})$ in o or $\mathrm{M} \mathrm{HCl}-0.025 \mathrm{M} \mathrm{NaCl}$. Fractions of $0.6 \mathrm{ml}$ were collected. 


\section{TABLE 1}

AMINO ACID COMPOSITION OF BOVINE SFERM HEAD PROTEINS

Values are given in molar ratios.

$\begin{array}{lll}\text { Amino Fractionl Fraction II } & \text { Fraction II } \\ \text { acad } & \text { after } \\ & \text { Purification } \\ & \text { on Amberlite } \\ & \text { IRC-50 }\end{array}$

\begin{tabular}{|c|c|c|c|}
\hline 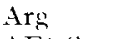 & 3.2 & 23.6 & $24 \cdot 3$ \\
\hline AEt cys & 1.4 & 5.7 & 5.9 \\
\hline Thr & 34 & 30 & 30 \\
\hline Tyr & $1+4$ & 20 & 20 \\
\hline Ser & +4 & 20 & 1.9 \\
\hline Val & 3.0 & 20 & 211 \\
\hline Gly & 38 & 21 & 21 \\
\hline Tle & 2. I & 10 & I. \\
\hline Leu & 4.0 & 1,0 & 10 \\
\hline Mla & 3.9 & 1.0 & 10 \\
\hline His & I. 3 & I 0 & 1.0 \\
\hline Phe & I.X & 1.0 & I. 0 \\
\hline Glu & $6 \mathrm{~T}$ & I I & 1.0 \\
\hline$A s p$ & $4 \cdot 3$ & 0.1 & 0 \\
\hline Pro & $3 \cdot 5$ & 01 & b \\
\hline Lys & 3.2 & $O I$ & () \\
\hline Met & 10 & 1) & (1) \\
\hline
\end{tabular}

guanidiniun chloride in water. Subsequently the solution was dialyzed against 7 changes of $0.25 \mathrm{M} \mathrm{HCl}$ at $4^{\circ}$ for 2 days. Virtually all of the original protein was recovered after dialysis indicating the absence of proteolysis. A precipitate containing all of the DNA and 5-I0\% of the protein originally present in the sperm heads was removed by centrifugation. The supernatant solution, containing 90-95\% of the original sperm head protein, was dialyzed against 4 changes of distilled water at 4 for $40 \mathrm{~h}$. The dialyzed solution was concentrated in a rotary evaporator at $30^{\circ}$ and subsequently applied to a Sephadex $(\mathrm{r}-75$ column $(\mathrm{I} .8 \mathrm{~cm}$ ․ $40 \mathrm{~cm})$ equilibrated with $0.0 \mathrm{M} \mathrm{HCl}-0.025 \mathrm{M} \mathrm{NaCl}$. The column was developed with the same solvent. As depicted in Fig. I two fractions were obtained. The first fraction comprised $25^{\circ} \%$ of the protein, the second fraction $75^{\circ} \circ$. Amino acid analyses (Table I) indicated that the second fraction was a strongly basic protein rich in arginine and cysteine. This second fraction was submitted to a final purification by means of chromatography on an Amberlite IRC -50 column $(2 \mathrm{~cm} \text {. Io } \mathrm{cm})^{4}$. A small amount $\left(2^{\circ}{ }_{1}\right)$ of contaminating material was eluted with $0.2 \mathrm{M}$ acetic acid, while the main fraction $\left(980_{\circ}^{\circ}\right)$ was eluted with $0.05 \mathrm{M} \mathrm{HCl}$. The amino acid composition of this fraction is shown in Table I.

When examined for purity by electrophoresis $(\mathrm{pH}+2)$ in a $0^{\circ}{ }_{0}^{\circ}$ polyacrylamide gel, the basic protein migrated as a single band. In sedimentation velocity studies with $0.75^{\circ}$, solutions of the basic protein in $0.2 \mathrm{M} \mathrm{KCl}, 0.05 \mathrm{M}$ Tris $-\mathrm{HCl}(\mathrm{pH} 8.0$ ) in a Spinco Model E ultracentrifuge, using a synthetic boundary cell, the material sedimented as a homogeneous substance at $59780 \mathrm{rev} / \mathrm{min}$ (Fig. 2). Determination of $\mathrm{NH}_{2}$-terminal amino acids by the cyanate method ${ }^{5}$ revealed the presence of a single $\mathrm{NH}_{2}$-terminal amino acid, alanine. The amount of $\mathrm{NH}_{2}$-terminal alanine was at least 
$80 \%$ of the total amount of alanine found in the protein. This indicated that all of the alanine in the protein is probably $\mathrm{NH}_{2}$-terminal. For the determination of the carboxyl-terminal amino acids the protein was digested with carboxypeptidase A (Worthington, DFP treated) at $\mathrm{pH} 8.0$ according to $A M B \mathrm{BER}^{6}$, using a molar ratio of enzyme to substrate of $\mathrm{I}: \mathrm{IOO}$. The released amino acids were separated from the remaining protein by chromatography on an Amberlite IRC-5o column according to ToBITA et $a l .{ }^{4}$. The released amino acids were eluted with $0.2 \mathrm{M}$ acetic acid. To discriminate between glutamine and threonine, which run together in the Technicon analytical system, the following procedure was followed.

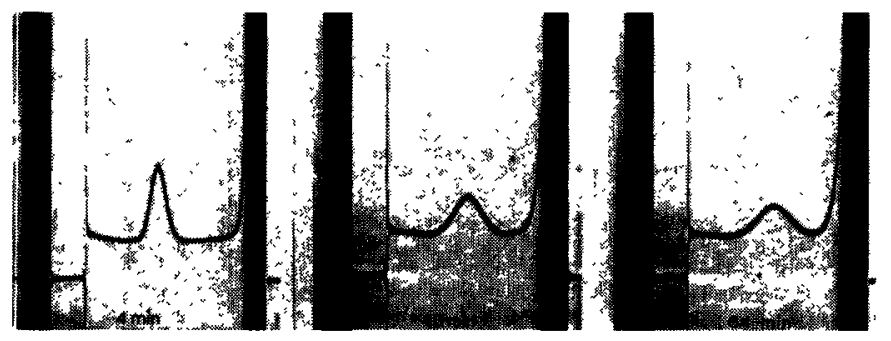

Fig. 2. Sedimentation velocity pattern of the basic head protein in a synthetic boundary cell, $4,4^{\circ}$ and $64 \mathrm{~min}$ after attaining full speed. Sedimentation was performed at $597^{\circ} 8 \mathrm{rev} / \mathrm{min}$ at $20^{\circ}$. The direction of sedimentation was from left to right. The solution contained $7.5 \mathrm{mg}$ of protein per $\mathrm{ml}$ of $0.2 \mathrm{M} \mathrm{KCl}, 0.05 \mathrm{M}$ Tris- $\mathrm{HCl}(\mathrm{pH} \mathrm{8.0)}$ ).

The amino acid fraction was evaporated to dryness, hydrolyzed for $\mathrm{I} h$ in $\mathrm{I} M$ $\mathrm{HCl}$ at $100^{\circ}$ and analyzed. Another portion of the amino acid fraction was analyzed without hydrolysis. An enzyme blank and a protein blank were determined in the same way. These analyses showed that a single amino acid, glutamine, was released upon carboxypeptidase A digestion. The amount of carboxyl-terminal glutamine equals the amount of glutamic acid in the protein, which indicates that all glutamic acid in the protein is present as carboxyl-terminal glutamine.

The data of the end group analyses, together with the results of the electrophoretic and sedimentation velocity studies indicate that the isolated basic protein fraction is probably homogeneous.

The amino acid analysis of the basic protein, together with the data of the end group analyses, suggest the following composition: Ala $\left(\operatorname{Arg}_{24}, \mathrm{Cys}_{6}, \mathrm{Thr}_{3}, \mathrm{Tyr}_{2}, \operatorname{Ser}_{2}\right.$, $\mathrm{Gly}_{2}, \mathrm{Val}_{2}, \mathrm{Leu}_{1}, \mathrm{Ile}_{1}, \mathrm{Phe}_{1}, \mathrm{His}_{1}$ ) Gln. The molecular weight calculated from this composition is 6200 .

The basic protein which, apart from the presence of 6 cysteine residues, closely resembles the protamines of fish spermatozoa, originates most probably in the nuclei of the sperm heads. Our results thus support the hypothesis advanced earlier by BRIL-PETERSEN AND WESTENBRINK ${ }^{1}$ according to which in the compact nucleus of bull spermatozoa the DNA is associated with a network of keratinoid threads which are rich in arginine. Our results suggest that such a network is composed of identical subunits of low molecular weight that are cross-linked by numerous disulfide bonds.

Laboratory for Physiological Chemistry,

J. P. Coelingh

The State University,

Utrecht (The Netherlands)

T. H. RozIjN

C. H. Monfoort 


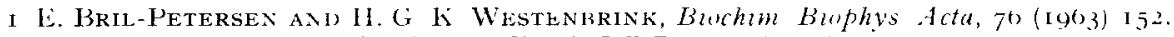

2 D. M. Henricks anid D T Mayer, Exptl. Cell Res., to (ig65) foz.

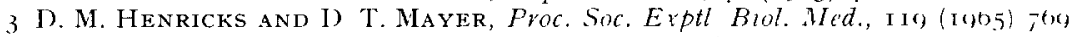

+ T. Tobita, M. Yamasaki, T. Ando, J Blochem., 63 (I968) II9.

5 G. R. Stark and I). G. Smyth, J. Blol. Chem., $238(1963) 214$

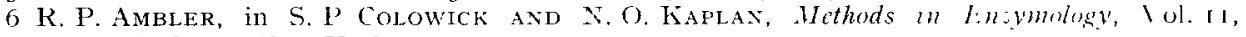
Academic Press, New York, I 967, p. I 55

Received June $25^{\text {th }}$, Ig(o)

Buchem. Buphys Acta, ISi (1060) 35.3-35' 